Revista Brasileira de Agricultura Irrigada v.11, nº.5, p. 1732 - 1737, 2017

ISSN 1982-7679 (On-line)

Fortaleza, CE, INOVAGRI - http://www.inovagri.org.br

DOI: $10.7127 /$ rbai.v11n500790

Protocolo 790.17 - 23/05/2017 Aprovado em 31/08/2017

\title{
EFFICIENCY IN WATER USE AND YIELD OF OKRA (Abelmoschus esculentus) IN RESPONSE TO DIFFERENT LEVELS OF IRRIGATION
}

\author{
Diego Bispo dos Santos Farias ${ }^{1}$, Ariovaldo Antonio Tadeu Lucas², Rychardson Rocha de \\ Araújo $^{2}$, Maria Iderlane de Freitas ${ }^{3}$, Tiago Silva de Jesus ${ }^{4}$
}

\begin{abstract}
The objective of this work was to determine the irrigation levels that result in the maximum productivity and efficient use of water for the cultivation of okra. The experiment had five irrigation levels (25, 50, 75, 100 and 125\% of crop evapotranspiration-ETc) and a control plot that did not receive irrigation. The experimental design was in randomized blocks, with four replications. Irrigations were applied through a drip system and for irrigation management, the FAO Penman-Monteith standard method was used to estimate the reference evapotranspiration, and crop evapotranspiration was obtained through a constant water table lysimeter installed in the area experimental. The productivity was obtained considering the production of the useful area of each plot with subsequent conversion to $\mathrm{kg}$.ha- ${ }^{-1}$. The efficiency of water use was determined by dividing the amount produced in kg of fruits per millimeter of water applied in okra culture. The application of different irrigation levels influenced in a significant way the variables analyzed in this experiment.
\end{abstract}

Keywords: Water economy; irrigation management; horticulture

\section{EFICIÊNCIA NO USO DA ÁGUA E PRODUÇÃO DE QUIABO (Abelmoschus esculentus) EM RESPOSTA A DIFERENTES NÍVEIS DE IRRIGAÇÃO}

\footnotetext{
RESUMO

O objetivo do presente estudo foi avaliar a produção de quiabo em diferentes níveis de irrigação, na região Nordeste do estado de Sergipe. O experimento teve cinco níveis de irrigação (25, 50,

${ }^{1}$ Graduating in Agronomic Engineering - Federal University of Sergipe, PC - 49100 000; São Cristóvão, Sergipe, Brazil. Email: diegotrust@gmail.com

${ }^{2}$ Professor, Department of Agricultural Engineering - Federal University of Sergipe, PC - 49100 000; São Cristóvão, Sergipe, Brazil. Email: aatlucas@gmail.com

${ }^{3}$ Graduating in Agronomic Engineering - Federal University of Sergipe, PC - 49100 000; São Cristóvão, Sergipe, Brazil. Email: freitasiderlane@gmail.com

${ }^{4}$ Graduating in Agricultural Engineering - Federal University of Sergipe, PC - 49100 000; São Cristóvão, Sergipe, Brazil. Email: tiago_titi752@hotmail.com
} 
75, 100 e 125\% da evapotranspiração-ETc) e uma parcela de controle que não recebeu irrigação. O delineamento experimental foi em blocos casualizados, com quatro repetições. As irrigações foram aplicadas através de um sistema de gotejamento, e para o manejo da irrigação, o método padrão da FAO Penman-Monteith foi utilizado na estimativa da evapotranspiração de referência e a evapotranspiração da cultura foi obtida através de um lisímetro de lençol freático constante instalado na área experimental. A produtividade foi obtida considerando a produção da área útil de cada parcela com subsequente conversão em $\mathrm{kg}$. ha ${ }^{-1}$. A eficiência de uso da água foi determinada pela divisão da quantidade produzida em kg de frutos por milímetro de água aplicada em cultura de quiabo. A aplicação de diferentes níveis de irrigação influenciou de forma significativa as variáveis analisadas neste experimento.

Keywords: Economia da água; manejo da irrigação; horticultura

\section{INTRODUCTION}

The okra (Abelmoschus esculentus L.) is a popular vegetable with high nutritional value, great acceptance in the market and belongs to the Malvácea family. It is cultivated mainly in tropical regions and it has fast cycle and resistance to some pests. The small producers are the main responsible for much of the production of this vegetable. As a result of the increasing consumer preference, there has been a significant expansion of the okra in Brazil, especially in the states of Rio de Janeiro, São Paulo and Sergipe (CAVALCANTE et al., 2010; PAES et al., 2012).

Nowadays, the sector that consumes the most water in Brazil is agriculture, and due to the scarcity of this resource, it is necessary to manage irrigation rationally and take care to the implementation of irrigation systems, so they can work more efficiently, reducing waste in irrigated agriculture (Vieira, 2012). Through the efficient irrigation use, irrigated crops do not suffer water stress, improving their productive characteristics (Inman-Bamber and Smith, 2005). The efficiency in the use of water is given by the quotient between the productivity of a crop and the amount of water applied throughout its cycle (Pereira et al., 2002).

To manage efficiently the irrigation farmers should carried out techniques that apply water to crops based on crop coefficients that correspond to the actual water requirements demanded by the growing conditions (Gomes et al., 2010).
The purpose of this work was to evaluate the efficiency in water use and productivity of okra culture by applying different water depths as a function of crop evapotranspiration.

\section{MATERIALS AND METHODS}

This work was carried out at the Experimental Station of the Agronomic Engineering Department, Federal University of Sergipe - UFS, located in the central portion of the physiographic region of Sergipe State, 15 $\mathrm{km}$ from Aracaju, at the geographic coordinates of $10^{\circ} 55^{\prime} 27^{\prime \prime}$ south latitude and $37^{\circ} 12^{\prime} 0^{\prime \prime}$ west longitude, with an altitude of 46 meters. The local climate according to Köppen's classification is As type, wich is tropical rainy with dry summer and $1200 \mathrm{~mm}$ annually of rainfall, concentrated in the months of April to September.

The local soil is Red Yellow Argisol Distrophic, with textural B horizon, according to Embrapa (2013), with the following chemical characteristics in the 0-0.20 m layer: $\mathrm{pH}\left(\mathrm{H}_{2} \mathrm{O}\right) 5.9 ; 10.7 \mathrm{mg} \mathrm{dm}^{-3}$ of P (Mehlich 1); $29 \mathrm{mg} \mathrm{dm}^{-3} \mathrm{~K}$; $1.41 \mathrm{cmolc} \mathrm{dm}^{-3} \mathrm{Ca} ; 1.12 \mathrm{cmol}$ $\mathrm{dm}^{-3} \mathrm{Mg} ; 0.0$ cmolc dm ${ }^{-3} \mathrm{Al} ; 7.10 \mathrm{mg} \mathrm{dm}^{-3} \mathrm{Na}$ (Mehlich 1).

The experimental design was in randomized blocks, with six treatments and four replications; the experimental unit consisted of a seven meter long plant line containing twenty three plants spaced $1.0 \times 0.3$ $\mathrm{m}$ and only twenty-one plants were evaluated due to the elimination of the border. The treatments consisted of the application of six 
irrigation water depths $(0,25,50,75,100$ and $125 \%$ of crop evapotranspiration).

The sowing was done manually, on fifteenth day of March of 2017, and three seeds were distributed per hole. The hole were opened manually with the aid of a hoe. Tha fertilization was carried out according to the indication for okra culture in the state of Sergipe and based on results of soil analysis. The weeds were controlled throughout the experiment by manual weeding.

The irrigation management was carried out based on crop and reference evapotranspiration, follow by irrigation time calculated in a spreadsheet using Kc values at the different stages of the okra crop presented by Farias (2016) for the region of São Cristóvão, SE. The meteorological data for the determination of the reference evapotranspiration were obtained through Meteorological Stations of the National Institute of Meteorology (INMET), located in Aracaju - SE.

For the estimation of reference evapotranspiration - ETo in the daily scale, the Penman-Monteith model adapted by Allen et al. (1989), given by Equation 1, was used.

$$
\text { ETo }=\frac{0,4082 \Delta\left(R_{n}-G\right)+\gamma^{*} \frac{900}{T+273} u_{2}\left(e_{s}-e_{a}\right)}{\Delta+\gamma^{*}\left(1+0,34 u_{2}\right)}
$$

where: ETo - reference evapotranspiration $\left(\mathrm{mm} \mathrm{d}^{-1}\right) ; \Delta$ - slope of the saturation vapor pressure curve $\left(\mathrm{kPa}^{\circ} \mathrm{C}^{-1}\right) ; \gamma^{*}$ psychrometric constant $=0.063 \mathrm{kPa}^{\circ} \mathrm{C}^{-1} ; \mathrm{R} \mathrm{n}$ - surface radiation balance $\left(\mathrm{MJ} \mathrm{m}^{-2} \mathrm{~d}^{-1}\right) ; \mathrm{G}$ - heat flow in soil $\left(\mathrm{MJ} \mathrm{m}^{-2} \mathrm{~d}^{-1}\right) ; \mathrm{T}$ - average air temperature $\left({ }^{\circ} \mathrm{C}\right)$; $\mathrm{U}_{2}$ - wind speed measured at 2 meters height $\left(\mathrm{m} \mathrm{s}^{-1}\right)$; es - vapor saturation pressure $(\mathrm{kPa})$; and - steam partial pressure (kPa); (And s - and a) - vapor saturation deficit (kPa).

For the calculation of crop evapotranspiration, Equation 2 was used:

$$
E T c=E T o * K c
$$

where: Kc - crop coefficient; ETc - crop evapotranspiration (mm); ETo - reference evapotranspiration.

The water depth (Wd) applied in each treatment was determined by Equation 3:

$$
W d=\left(\frac{E T c}{E f}\right)-P
$$

where: $\mathrm{ETc}=$ crop evapotranspiration $(\mathrm{mm})$; $\mathrm{Wd}=$ water depth applied in each plot $(\mathrm{mm}) ; \mathrm{P}=$ Precipitation in the period (mm); $E f=$ Irrigation system efficiency.

For the irrigation, a gravity irrigation system was used, supplied by a water tank of $1000 \mathrm{~L}$, the irrigation hose working with selfcompensating drippers, with a flow rate of approximately $2 \mathrm{~L} . \mathrm{h}^{-1}$, and each plant had one dripper.

The irrigation schedule was fixed, that is, the irrigation was performed every day, varying the water depth applied as a function of the crop evapotranspiration, except periods that had precipitations. The control of the irrigation time and the applied water depth was performed manually, through individual records for each treatment.

The first harvest occured at 52 days after sowing, the followings harvested crops were each three day interval, with a total of six harvested along the crop cycle. Thus, the variables: Yield (Y) and Water use efficiency (WUE), were analyzed in each harvest.

The productivity was obtained considering the production of the useful area of each plot with subsequent conversion to $\mathrm{kg} \mathrm{ha}^{-1}$.

The results were submitted to the analysis of variance, with effects ranging, according to their significance, the means compared by the $\mathrm{F}$ and Tukey tests at the $5 \%$ probability level, using the ASSISTAT statistical program (Silva \& Azevedo, 2002). The choice of the regression model was made based on the model of greater degree significant by the test F. 


\section{RESULTS AND DISCUSSION}

During the experiment the average temperature was $28^{\circ} \mathrm{C}$ and the average relative humidity was $66.5 \%$. The accumulated precipitation was $456.8 \mathrm{~mm}$, so that even the smallest water depth could present positive results.

The precipitation values observed during the cultivation period in the field can be seen in Figure 1, and the highest precipitation was observed on nineteenth day May of 2017, with a value of $130.8 \mathrm{~mm}$.

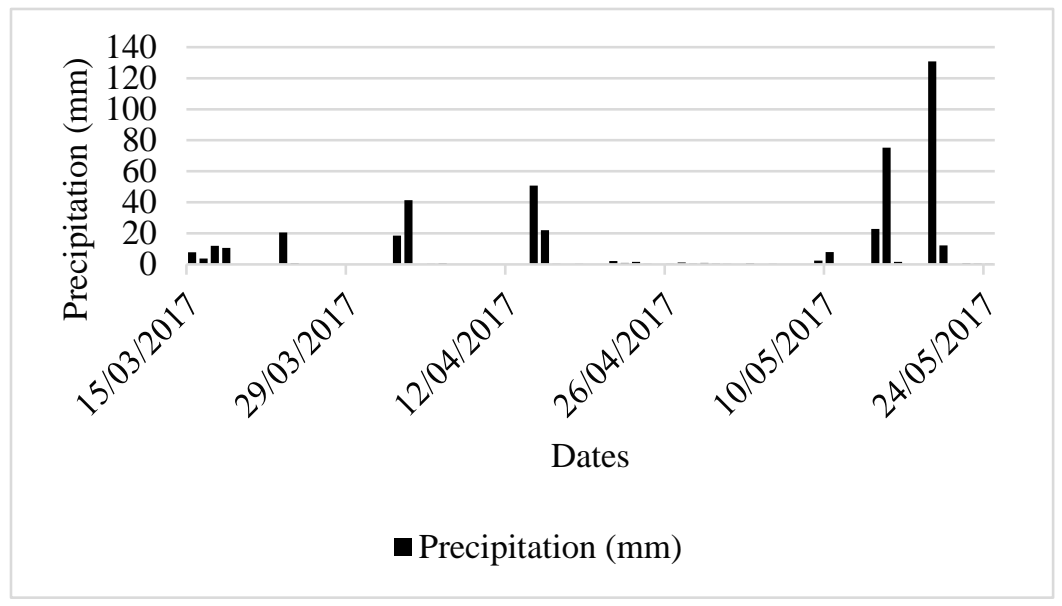

Figure 1. Daily precipitation in $\mathrm{mm}$, during the experimental period. São Cristóvão, SE, 2017.

From the analysis of variance, it was observed that the Water use efficiency (WUE) and Yield (Y) were significantly influenced by the different irrigation depths, by the $\mathrm{F}$ test $(\mathrm{p}<0.01)$, as can be seen in Table 1.

Table 1. Summary of the variance analysis for the Yield (Y) and Water Use Efficiency (WUE) as a function of the irrigation depths in okra culture in São Cristóvão, SE, 2017.

\begin{tabular}{cccc}
\hline & & \multicolumn{2}{c}{ Average Squares } \\
\cline { 3 - 4 } SV & GL & WUE & Y \\
\cline { 3 - 4 } Levels & 3 & $623.80^{* *}$ & $231.361^{* *}$ \\
Blocks & 5 & 9.26 & 2.6871 \\
Error & 15 & 6.6 & 1.82403 \\
\hline Mean & - & 18.95 & 10.375 \\
\hline Cv $(\%)$ & - & 13.58 & 13.02 \\
\hline
\end{tabular}

The water depth that provided the highest yield value $\left(0.6325 \mathrm{~kg}\right.$ plant $\left.^{-1} ; 21.09 \mathrm{t} \mathrm{ha}^{-1}\right)$ was $132.2 \mathrm{~mm}(125 \%$ ETc) and the lowest $(0.0775$ $\mathrm{kg}$ plant $^{-1} ; 2.58 \mathrm{t} \mathrm{ha}^{-1}$ ) a of $0 \mathrm{~mm}$, equivalent to $0 \%$ of ETc, as we can seen in Table 2, as well as, the diferences among the treatments.

Table 2. Mean of Yield (Y) and Water Use Efficiency (WUE) as a function of the irrigation depths in okra culture in São Cristóvão, SE, 2017.

\begin{tabular}{|c|c|c|}
\hline Treatments & Yield (t.ha $\left.{ }^{-1}\right)$ & WUE $\left(\mathrm{Kg} \cdot \mathrm{ha}^{-1} \cdot \mathrm{mm}^{-1}\right)$ \\
\hline 0\% ЕТс & $2,583 \mathrm{~d}$ & $5,65 d$ \\
\hline $25 \%$ ЕTс & $4,168 \mathrm{~cd}$ & $8,71 \mathrm{~cd}$ \\
\hline $50 \%$ ЕТс & 6,918 bc & $13,67 \mathrm{bc}$ \\
\hline
\end{tabular}




\begin{tabular}{lcc}
$75 \%$ ETc & $9,248 \mathrm{~b}$ & $17,33 \mathrm{~b}$ \\
$100 \%$ ETc & $18,25 \mathrm{a}$ & $32,51 \mathrm{a}$ \\
$125 \%$ ETc & $21,09 \mathrm{a}$ & $35,80 \mathrm{a}$ \\
\hline CV $(\%)$ & 13,02 & 13,58 \\
\hline Mean followed by the same letter in a row not differ statically among then by the test Scott-Knott to 5\%.
\end{tabular}

For this variable, linear increases were observed as a function of the increase of the applied water depth (Figure 2). The lower productivity can be associated with the water stress caused in plants, because the plants when

they suffer water déficit this stress tend to close their stomata and thus reduce the photosynthetic rate, causing them not to produce efficiently well, causing a reduction in the productive characteristics of the fruits.

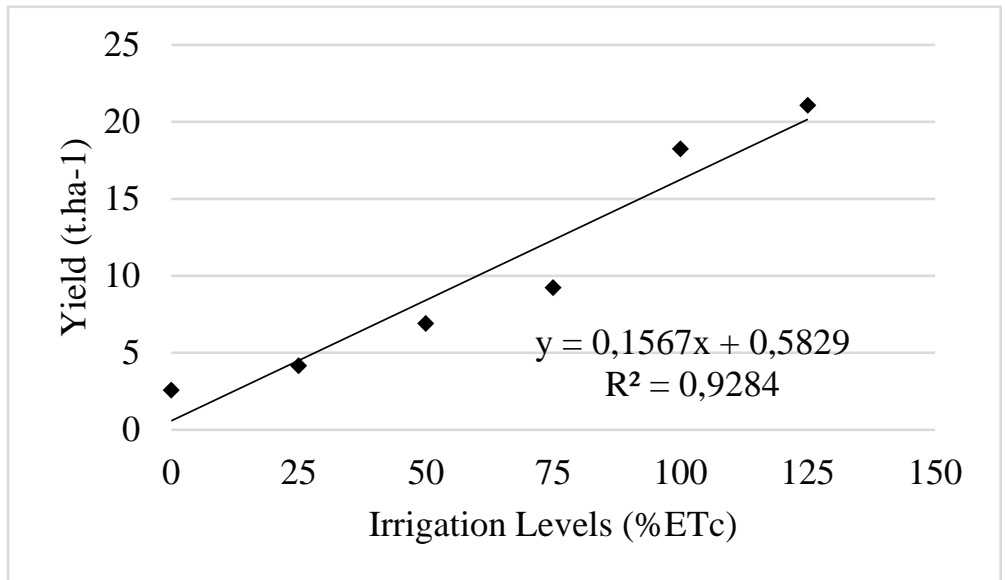

Figure 2. Yield, as a function of the irrigation levels in okra culture in São Cristóvão, SE, 2017.

Andrade Júnior et al. (2002), working with cowpea cv. Gurguéia under different irrigation depths, verified that the increase of the irrigation dpeth from a great point caused a decrease of the production. While in the present work, the water depth above $100 \%$ of ETc was the one that obtained the highest productivity, in contrast to the experiment previously mentioned.

The water depth that provided the highest Water Use Efficiency (WUE) (35.80 kg.ha$\left.{ }^{1} . \mathrm{mm}^{-1}\right)$ was $132.2 \mathrm{~mm}$ (125\% of ETc) and the lowest (5.65 kg.ha-1. $\left.\mathrm{mm}^{-1}\right)$ a of $0 \mathrm{~mm}$, equivalent to $0 \%$ of ETc. For this variable, linear increases were observed as a function of the increase of the applied water depth (Figure 3). The greater WUE, is associated with greater productivity and the greater availability of water for the plants, allowing the plants to extract better the soil solution, thus to take advantage of the nutrients, besides being able to carry out the photosynthesis without impediments. Dagdelen et al. (2009) observed that there was an increase in the WUE when the $25 \%$ of the water depth was applied, reaching $1.46 \mathrm{~kg} \mathrm{~m}^{-3}$, while in irrigation with $100 \%$ ETc the WUE was $0.81 \mathrm{~kg} \mathrm{~m}^{-3}$. 


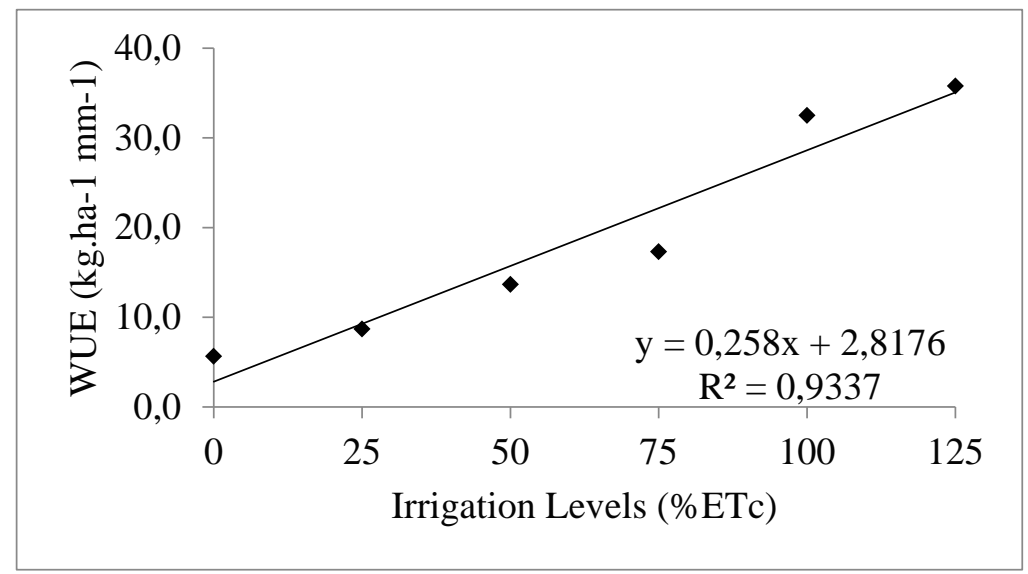

Figure 3. Water Use Efficiency (WUE), as a function of the irrigation levels in okra culture in São Cristóvão, SE, 2017.

Singh et al. (2010), working with water deficit in cotton in semi-arid region, they found a significant effect in relation to the WUE for the different irrigation depths studied, where the $100 \%$ ETc irrigation water depth obtained a value of $0.54 \mathrm{~kg} . \mathrm{m}^{-3}$, and the $50 \%$ ETc water depth obtained a value of $0.64 \mathrm{~kg} \cdot \mathrm{m}^{-3}$.

\section{CONCLUSION}

The results showed that the Water use efficiency (WUE) and Yield (Y) were influenced by the different irrigation depths. The water depth that farmers can use for okra crop is $100 \%$ of ETc that provide a yield no different from $125 \%$ of ETc.

\section{BIBLIOGRAPHY}

ALLEN, R.G.; PEREIRA, L.S.; RAES, D.; SMITH, M. Crop evapotranspiration: guidelines for computing crop water requirements. Rome: FAO, 1998. 301p. (FAO Irrigation and Drainage, Paper 56).

ANDRADE JUNIOR, A.S.; RODRIGUES, B.H.N.; FRIZZONE, J.A.; et al. Níveis de irrigação na cultura do feijão caupi. Revista Brasileira Engenharia Agrícola Ambiental, Jan./Apr. 2002, vol.6, no.1, p.17-20.

CAVALCANTE, L. F. et al. Teores foliares de macronutrientes em quiabeiro cultivado sob diferentes fontes e níveis de matéria orgânica. Seminário de Ciências agrárias, Londrina, PR. Anais. v. 31, n. 1, p. 19-28, jan.-mar., 2010.

DAGDELEN, N.; BASAL, H.; YILMAZ, E.; GURBZ, T.; AKCAY, S. Different drip irrigation regimes affect cotton yield, water use efficiency and fiber quality in western Turkey. Agricultural Water Management, v.96, n.1, p.111-120, 2009.

INMAN-BAMBER, N.G.; SMITH, D.M. Water relations in sugarcane and response to water deficit. Field Crop Research, Amsterdam, v. 92, p. 185-202, 2005.

PAES, H. M. F.; ESTEVES, B. dos S.; SOUSA, E. F, de. Determinação da demanda hídrica do quiabeiro em Campos dos Goytacazes, RJ. Revista Ciência Agronômica, Fortaleza, v. 43, n. 2, p. 256-261, 2012.

SINGH, Y.; RAO, S. S.; REGAR, P. L. Deficit irrigation and nitrogen effects on seed cotton yield, water productivity and yield response factor in shallow soils of semi-arid environment. Agricultural Water Management, v.97, p.965-970, 2010.

VIEIRA, G. H. S. Uso racional da água na cultura da cana-de-açucar irrigada no norte de Minas Gerais. Tese, Viçosa - MG, 101p. 2012. 